\title{
Protective Effect of Baccharis trimera Extract on Acute Hepatic Injury in a Model of Inflammation Induced by Acetaminophen
}

\author{
Bruno da Cruz Pádua, ${ }^{1,2}$ Joamyr Victor Rossoni Júnior, \\ Cíntia Lopes de Brito Magalhães, ${ }^{1,3}$ Míriam Martins Chaves, ${ }^{4}$ \\ Marcelo Eustáquio Silva, ${ }^{1,5}$ Maria Lucia Pedrosa, ${ }^{1,3}$ Gustavo Henrique Bianco de Souza, ${ }^{6}$ \\ Geraldo Célio Brandão, ${ }^{6}$ Ivanildes Vasconcelos Rodrigues, ${ }^{7}$ \\ Wanderson Geraldo Lima, ${ }^{1,3}$ and Daniela Caldeira Costa ${ }^{1,3}$ \\ ${ }^{1}$ Programa de Pós-graduação em Ciências Biológicas do Núcleo de Pesquisas em Ciências Biológicas (NUPEB), \\ Universidade Federal de Ouro Preto (UFOP), 35.400-000 Ouro Preto, MG, Brazil \\ ${ }^{2}$ Centro Federal de Educação Tecnológica de Minas Gerais (CEFET/MG), 35.790-970 Curvelo, MG, Brazil \\ ${ }^{3}$ Departamento de Ciências Biológicas (DECBI), Instituto de Ciências Exatas e Biológicas, Universidade Federal de Ouro Preto (UFOP), \\ 35.400-000 Ouro Preto, MG, Brazil \\ ${ }^{4}$ Departamento de Bioquímica e Imunologia, Instituto de Ciências Biológicas, Universidade Federal de Minas Gerais (UFMG), \\ Cx. Postal 486, 30.161-970 Belo Horizonte, MG, Brazil \\ ${ }^{5}$ Departamento de Alimentos, Escola de Nutrição, Universidade Federal de Ouro Preto (UFOP), 35.400-000 Ouro Preto, MG, Brazil \\ ${ }^{6}$ Programa de Pós-graduação em Ciências Farmacêuticas (CIPHARMA), Escola de Farmácia, \\ Universidade Federal de Ouro Preto (UFOP), 35.400-000 Ouro Preto, MG, Brazil \\ ${ }^{7}$ Núcleo de Pesquisas em Produtos Naturais e Sintéticos, Departamento de Física e Química, \\ Faculdade de Ciências Farmacêuticas de Ribeirao Preto, Universidade de São Paulo (USP), 14040-903 São Paulo, SP, Brazil
}

Correspondence should be addressed to Bruno da Cruz Pádua; brunobioufop@yahoo.com.br

Received 7 July 2014; Revised 13 September 2014; Accepted 8 October 2014; Published 12 November 2014

Academic Editor: Muzamil Ahmad

Copyright (C) 2014 Bruno da Cruz Pádua et al. This is an open access article distributed under the Creative Commons Attribution License, which permits unrestricted use, distribution, and reproduction in any medium, provided the original work is properly cited.

Background. Acetaminophen (APAP) is a commonly used analgesic and antipyretic. When administered in high doses, APAP is a clinical problem in the US and Europe, often resulting in severe liver injury and potentially acute liver failure. Studies have demonstrated that antioxidants and anti-inflammatory agents effectively protect against the acute hepatotoxicity induced by APAP overdose. Methods. The present study attempted to investigate the protective effect of $B$. trimera against APAP-induced hepatic damage in rats. The liver-function markers ALT and AST, biomarkers of oxidative stress, antioxidant parameters, and histopathological changes were examined. Results. The pretreatment with $B$. trimera attenuated serum activities of ALT and AST that were enhanced by administration of APAP. Furthermore, pretreatment with the extract decreases the activity of the enzyme SOD and increases the activity of catalase and the concentration of total glutathione. Histopathological analysis confirmed the alleviation of liver damage and reduced lesions caused by APAP. Conclusions. The hepatoprotective action of B. trimera extract may rely on its effect on reducing the oxidative stress caused by APAP-induced hepatic damage in a rat model. General Significance. These results make the extract of $B$. trimera a potential candidate drug capable of protecting the liver against damage caused by APAP overdose.

\section{Introduction}

The liver is the major site of detoxification and the primary target of drug exposure in the body [1]; therefore, druginduced liver injury is a significant public health problem, accounting for over half of all cases of acute liver failure [2].

Acetaminophen (APAP) is a commonly used analgesic and antipyretic agent. At therapeutic doses, it is usually safe and well tolerated. However, acute acetaminophen overdose 
causes severe and fatal hepatotoxicity [3]. Some individuals experience APAP toxicity even at therapeutic doses of less than $4 \mathrm{~g} / \mathrm{day}$, and, in pediatric populations, the majority of APAP overdoses are unintentional [4]. Moling et al. [5] reported a case of severe hepatotoxicity after therapeutic doses of APAP in an adult man. In fact, APAP overdose is the most common cause of drug-induced acute liver failure in the United Kingdom and the United States [6, 7].

The toxicity of APAP is related to its bioactivation by cytochrome $\mathrm{P} 450$ to the electrophilic metabolite $\mathrm{N}$-acetyl benzoquinone imine (NAPQI). At therapeutic doses, NAPQI is efficiently detoxified by glutathione (GSH) and eliminated through urine or bile; however, at supratherapeutic doses, both the glucuronidation and sulfation pathways become saturated, and extensive bioactivation of APAP depletes the hepatic GSH pool and causes oxidative stress [8]. This oxidative stress may trigger signaling pathways to act through mitochondrial toxicity, ultimately causing cell death [1]. A significant amount of evidence has pointed to the potential involvement of oxidative stress in acetaminophen toxicity [9, $10]$.

Several studies have shown that antioxidants and antiinflammatory agents effectively protect against the acute hepatotoxicity induced by acetaminophen overdose [11-13].

Several herbal medicines, their active constituents and formulations, are used in the treatment of a wide variety of clinical diseases and provide benefit to societies. Their protective action is through antioxidant enzymes (e.g., SOD, CAT, GST, and GR), which modify many pathways and proteins, including the DNA damage/repair processes [14], Nrf-2 [15], and xenobiotic response elements [16], thus maintaining the prooxidant/antioxidant balance in the body [1].

In this context, we highlight Baccharis trimera, popularly known as "carqueja," a member of the Asteraceae family and a native shrub from South Brazil, Paraguay, Uruguay, and Argentina. Medicinal teas prepared from the aerial parts of this shrub are used in folk medicine to treat not only gastrointestinal and liver diseases but also inflammatory processes [17]. Because of these biological effects, research on the chemical composition of B. trimera was conducted and demonstrated that this plant has many bioactive compounds, such as flavonoids, diterpenes, and triterpenes [18]. Triterpenes have been reported to be primarily responsible for its antiinflammatory activity $[19,20]$, while the flavonoids, due to their antioxidant activity, have been linked to protecting the body against reactive oxygen species (ROS) [21].

This study was conducted to investigate the effect of $B$. trimera in the modulation of oxidative stress and to evaluate the preventive effect of $B$. trimera in acetaminophen-induced liver damage.

\section{Materials and Methods}

2.1. Reagents. The chemical reagents, including DTNB $\left[5,5^{\prime}-\right.$ dithio-bis (2-nitrobenzoic acid)], 2,4-dinitrophenylhydrazine (DNP), and thiobarbituric acid (TBA), were purchased from Sigma-Aldrich (St. Louis, MO, USA). Acetaminophen (APAP) $(200 \mathrm{mg} / \mathrm{mL})$ was obtained from Janssen-Cilag
Pharmaceuticals, Brazil. The kit for measuring serum alanine aminotransferase (ALT) and aspartate aminotransferase (AST) was from Diagnostic Labtest, Brazil.

2.2. Collection of Plant Material. The aerial parts of $B$. trimera were collected during August 2011 in the city of Ouro Preto, Minas Gerais, Brazil. The specimen, voucher number OUPR 22.127, was identified by Professor Viviane R. Scanlon and deposited in the Herbarium José Badini, UFOP.

2.3. Preparation of Extract. The aerial parts of the plant were dried in a ventilated oven, sprayed in a mechanical mill, and stored in plastic bottles. To obtain the hydroethanolic extract, approximately $100 \mathrm{~g}$ of the plant was extracted with distilled water and $70 \%$ alcohol at a ratio of $1: 1$ for $24 \mathrm{~h}$. Vacuum filtration and evaporation of the solvent in a rotovap were then performed. The crude extract that formed, with a percentage yield of $8-9 \%$, was then diluted with phosphatebuffered saline (PBS, $\mathrm{pH} 7.4$ ); a concentration of $600 \mathrm{mg} / \mathrm{kg}$ body weight was used in vivo. The methodology for the extract preparation was based on the work of Grance et al. [22] with some modifications.

2.4. LC-DAD-ESI-MS Analyses. Analyses were performed using an UPLC Acquity (Waters) ion trap mass spectrometer equipped with an atmospheric pressure chemical ionization (APCI) interface operated in the following conditions: positive and negative ion mode; capillary voltage, $3500 \mathrm{~V}$; capillary temperature, $320^{\circ} \mathrm{C}$; source voltage, $5 \mathrm{kV}$; vaporizer temperature, $320^{\circ} \mathrm{C}$; corona needle current, $5 \mathrm{~mA}$; and sheath gas, nitrogen, 27 psi. Analyses were run in the full scan mode $(100-2000 \mathrm{u})$. The ESI-MS/MS analyses were additionally performed in an UPLC Acquity (Waters) with helium as the collision gas, and the collision energy was set at $30 \mathrm{eV}$. Chromatographic separation was done on ACQUITY UPLC $\mathrm{BEH}(1.7 \mu \mathrm{m}, 50 \times 2 \mathrm{~mm}$ i.d.) (Waters). The mobile phase consisted of water $0.1 \%$ formic acid (solvent A) and acetonitrile $0.1 \%$ formic acid (solvent $\mathrm{B}$ ). The elution protocol was $0-11 \mathrm{~min}$, linear gradient from $5 \%$ to $95 \% \mathrm{~B}$. The flow rate was $0.3 \mathrm{~mL} \mathrm{~min}^{-1}$, and the sample injection volume was $4.0 \mu \mathrm{L}$. The UV spectra were registered from 190 to $450 \mathrm{~nm}$. Mass spectrometry analysis was performed on quadrupole instrument fitted with an electrospray source in the negative mode (Figure 1). Ion spray voltage: $-4 \mathrm{kV}$; orifice voltage: -60 V.

2.5. In Vitro Test: Cell Culture. The cell strains were acquired at the Cell Bank, Federal University of Rio de Janeiro (UFRJ). Liver cells were cultured in $75 \mathrm{~cm}^{2}$ growth vials (SARDEST) containing MEM culture medium. HEPES, 10\% (v/v) bovine fetal serum, and $1 \%(\mathrm{v} / \mathrm{v})$ of a mix of penicillin $(200 \mathrm{U} / \mathrm{mL})$ and streptomycin $(200 \mu \mathrm{g} / \mathrm{mL})$ were added to the medium. The vials were stored in oven at $37^{\circ} \mathrm{C}$ and humidified with $5 \%$ carbon dioxide $\left(\mathrm{CO}_{2}\right)$. This medium was replaced every two or three days depending on the confluence of the cell monolayer and the subcultures (passages) carried out. When the vials reached $100 \%$ confluence, the medium was vacuumed, and the cell monolayer was rinsed twice 


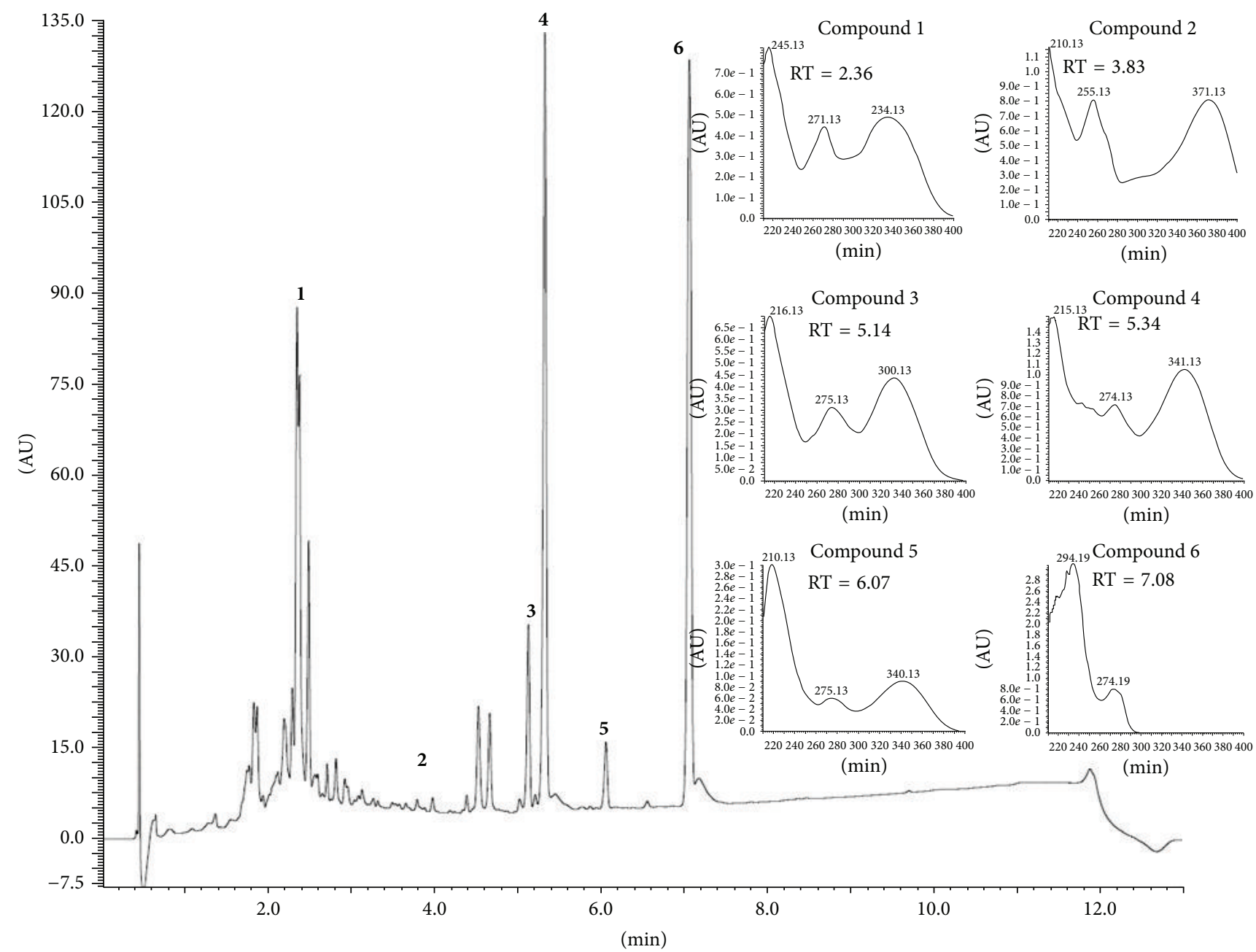

FiguRE 1: RP-UPLC-DAD profiles of hydroethanolic extract of B. trimera. Conditions: CHS130 100 RP-18 column $(1.7 \mu \mathrm{m}, 50 \times 3 \mathrm{~mm}$ i.d.). Elution was carried out with a linear gradient of water $0.1 \%$ formic acid (A) and acetonitrile $0.1 \%$ formic acid (B) (from 5\% to $95 \%$ of B in $11 \mathrm{~min}$ ) and the UPLC fingerprints were registered on a ACQUITY Waters apparatus with a UV-DAD detector (Waters 2996). Operating parameters of the mass spectrometer were capillary temperature $320^{\circ} \mathrm{C}$; spray needle voltage set at $3.50 \mathrm{kV}$; ES capillary voltage +3 and $-47 \mathrm{~V}$ for positive and negative polarity, respectively; and tube lens offset 0 and $-25 \mathrm{~V}$ for positive and negative polarity, respectively. Nitrogen was used as a sheath gas with a flow of 50 arbitrary units. Mass analysis was carried out in full-scan mode from 100 to 1.500 amu, in both positive and negative mode. UV spectra $(190-450 \mathrm{~nm})$ from the main peaks are shown inside on the chromatogram.

with phosphate-buffered saline solution without calcium and without magnesium (PBS). Later, to detach the monolayers, a solution of $0.20 \%$ trypsin and $0.02 \%$ EDTA was used. Next, the cell count was carried out with Trypan blue $0.3 \%$ in a Neubauer chamber.

2.6. Toxicity Assay with MTT. The cell line was acquired from the Cell Bank, Federal University of Rio de Janeiro (UFRJ). We added $5.0 \times 10^{3}$ HEPG2 in culture medium MEM $(10 \% \mathrm{v} / \mathrm{v}$ bovine fetal serum and $1 \% \mathrm{v} / \mathrm{v}$ mixture of penicillin/streptomycin). The plates were incubated in a humidified chamber with $5 \% \mathrm{CO}_{2}$ at $37^{\circ} \mathrm{C}$ for $1-72$ hours. After this time, the supernatant was removed, and $20 \mu \mathrm{L}$ MTT was added and incubated for 30 minutes. The absorbance was read at $570 \mathrm{~nm}$ in a microplate reader (Thermo Plate). HEPG2 was incubated in the presence of 1,2 , and $3 \%(50 \mu \mathrm{L})$ of the
B. trimera extract for 1 and 24 hours to assess cell viability. The calculation used to assess the percentage of cell viability was (absorbance of treated cells/absorbance control) $\times 100$. The control was assigned $100 \%$ viability.

2.7. In Vivo Test: Animals. The Laboratory of Experimental Nutrition of the Federal University of Ouro Preto (UFOP) provided the male albino Fischer rats used in the experiment; the animals were approximately 12 weeks old and weighed approximately $180 \mathrm{~g}$. All animals were kept in individual cages placed in an environment with controlled temperature, light, and humidity, and the animals received both commercial rat chow and water ad libitum. This work was conducted in accordance with the international standards of animal protection and with the ethical principles of the Brazilian College of Animal Experimentation, and the protocols were 
approved by the Ethics Committee on Animal Use (CEUA) of UFOP (OF 166/2011 protocol 2011/82).

For the experiments, thirty-two rats were divided into four groups according to their treatment. The control group (C) received $1.0 \mathrm{~mL} \mathrm{PBS}$, the $B$. trimera $(\mathrm{Bt})$ group received $600 \mathrm{mg} / \mathrm{kg}$ of the $B$. trimera extract, the acetaminophen (APAP) group received a single dose of $835 \mathrm{mg} / \mathrm{kg}$ acetaminophen, and the $B$. trimera + acetaminophen ( $\mathrm{Bt}+\mathrm{APAP})$ group received $600 \mathrm{mg} / \mathrm{kg}$ of the $B$. trimera extract and a single dose of $835 \mathrm{mg} / \mathrm{kg}$ acetaminophen an hour later. All treatments were administered by gavage and the interval between the B. trimera pre-treatments and APAP dose were based on the work of Meotti et al. [23] and Ajith et al. [24]. The animals were anesthetized and euthanized twenty-four hours after the APAP dose. The dose of APAP used and the experimental lining were based on the work of Yen et al. [25]. The animals that received $835 \mathrm{mg} / \mathrm{kg}$ APAP orally demonstrated, by the kit LabTest, a higher activity of ALT and AST. This increase in activity reached a peak 24 hours after the administration of APAP.

2.8. Preparation of Liver Tissue. The liver tissue was collected immediately after euthanasia of animals. To determine carbonyl protein concentrations, $200 \mathrm{mg}$ of tissue was homogenized in $50 \mathrm{mM}$ phosphate buffer ( $\mathrm{pH}$ 6.7) and $1 \mathrm{mM}$ EDTA. To determine the concentration of thiobarbituric acid reactive substances (TBARS), catalase and superoxide dismutase activity, $100 \mathrm{mg}$ of liver tissue was homogenized in phosphate buffer ( $\mathrm{pH}$ 7.4). Similarly, to determine total glutathione concentration, $100 \mathrm{mg}$ of liver tissue was homogenized in 5\% sulfosalicylic buffer. After homogenization, the samples were centrifuged at $10.000 \mathrm{~g}$ for 10 minutes at $4^{\circ} \mathrm{C}$. The supernatant was collected and used as the biological sample.

\subsection{Determination of Oxidative Stress Markers}

2.9.1. Thiobarbituric Acid Reactive Substances (TBARS). The TBARS concentration was determined based on thiobarbituric acid (TBA) binding to oxidized lipids. This measurement was performed according to Buege and Aust [26].

2.9.2. Carbonylated Protein. Protein oxidation by ROS leads to the formation of carbonyl derivatives, which can be measured by sensitive methods. Methods that use 2,4dinitrophenylhydrazine (DNPH), which reacts with carbonyl groups to generate the corresponding hydrazone and can then be analyzed spectrophotometrically, are especially useful. Measurements of carbonylated protein were performed according to Levine et al. [27].

\subsection{Determination of Antioxidant Defenses}

2.10.1. Superoxide Dismutase Activity (SOD). The activity of total superoxide dismutase (SOD) was measured using a kit (Cayman Chemical Company, MI, USA). Briefly, hepatic tissue was homogenized in cold 20 mM HEPES ( $\mathrm{pH}$ 7.2) containing $1 \mathrm{mM}$ EGTA, $210 \mathrm{mM}$ mannitol, and $70 \mathrm{mM}$ sucrose. Ten microliters of the supernatant was used in the test. The reaction was initiated by adding xanthine oxidase. The plate was incubated on a shaker for $20 \mathrm{~min}$ at room temperature, and the absorbance was measured at $450 \mathrm{~nm}$ using a plate reader (Biotek ELx808).

2.10.2. Catalase (CAT). Catalase activity was determined based on its ability to convert hydrogen peroxide $\left(\mathrm{H}_{2} \mathrm{O}_{2}\right)$ into water and molecular oxygen. The assays were performed as described by Aebi [28].

2.10.3. Total Glutathione Concentration. Glutathione is present in cells mainly in its reduced form (GSH), which represents approximately $90 \%$ of the total glutathione in the cell. The remaining amount is in the form of oxidized glutathione (GSSG). To determine the levels of total glutathione (GSG + GSSG) in our biological samples, we used a Sigma kit that employs a kinetic method based on the reduction of DTNB [5, $5^{\prime}$-dithiobis(2-nitrobenzoic acid)] to TNB, which can be spectrophotometrically measured at $412 \mathrm{~nm}$. A solution of reduced glutathione (G4251-Sigma) was used to determine the standard curve. Total glutathione is expressed in nmoles per $\mathrm{mL}$ of sample.

2.10.4. Glutathione Peroxidase Activity (GPx). The Glutathione Peroxidase Cellular Activity Assay kit (Sigma-Aldrich, St. Louis, MO, USA) was used to measure glutathione peroxidase activity in tissue extracts. The decrease in NADPH absorbance measured at $340 \mathrm{~nm}$ during the oxidation of $\mathrm{NADPH}$ to NADP is indicative of glutathione peroxidase activity because the enzyme is the rate-limiting factor of the coupled reactions. The enzyme activity is expressed as units/mL.

2.10.5. Glutathione Reductase Activity (GR). Glutathione reductase (GR) activity was measured using a kit (SigmaAldrich, St. Louis, MO, USA). Glutathione reductase is essential for the glutathione redox cycle to maintain adequate levels of reduced cellular GSH, which serves as an antioxidant that reacts with free radicals and organic peroxides. The activity of glutathione reductase was measured by following the increase in absorption caused by the reduction of DTNB at $412 \mathrm{~nm}$. The enzyme activity is expressed as units $/ \mathrm{mL}$.

2.11. Real-Time Quantitative RT-PCR Assay. The total RNA was extracted from $50 \mathrm{mg}$ tissue using Trizol reagent (Invitrogen Life Technologies, CA, USA) according to the manufacturer's protocol and resuspended in $30 \mu \mathrm{L}$ RNase-free water. The concentration and purity of RNA were estimated spectrophotometrically from the A260/A280 ratio (NanoVue, GE Healthcare, UK). A total of $1 \mu \mathrm{g}$ RNA was converted to cDNA using oligo (dT) and a High-Capacity cDNA Reverse Transcription Kit (Applied Biosystems, Foster City, CA, USA) according to the manufacturer's recommendations.

Quantitative real-time PCR (qPCR) was performed using the Power SYBR Green PCR Master Mix reagent (Applied Biosystems, Foster City, CA, USA) in a final reaction volume of $12 \mu \mathrm{L}$. The reaction included $0.1 \mu \mathrm{g} \mathrm{cDNA}$ and $0.5 \mu \mathrm{L}$ of each primer (forward and reverse, $10 \mu \mathrm{M}$ ). The forward 
TABLE 1: Flavonoids identified in the hydroethanolic extract of $B$. trimera by LC-DAD-ESI-MS.

\begin{tabular}{|c|c|c|c|c|c|}
\hline Peak & Compound & $\mathrm{RT}(\min )$ & $\mathrm{UV}(\mathrm{nm})$ & $\begin{array}{c}\text { LC-MS }[\mathrm{M}-\mathrm{H}]^{-} \\
(\mathrm{m} / z)\end{array}$ & $\begin{array}{c}\text { LC-MS }[\mathrm{M}+\mathrm{H}]^{+} \\
(m / z)\end{array}$ \\
\hline 1 & 5,3'-dihydroxy- $4^{\prime}$-methoxy-7-O-pyranosyl-furanosyl flavone & 2.36 & $\begin{array}{l}271.13 \\
332.13\end{array}$ & 563.49 & 565.38 \\
\hline 2 & Quercetin & 3.83 & $\begin{array}{c}255.13 \\
371.13\end{array}$ & 301.23 & 303.26 \\
\hline 3 & $3^{\prime}, 5$-Dihydroxy-4',7-dimethoxyflavone & 5.14 & $\begin{array}{l}275.13 \\
333.13\end{array}$ & 313.32 & 315.28 \\
\hline 4 & $3^{\prime}, 5$-Dihydroxy-4',6,7-trimethoxyflavone & 5.34 & $\begin{array}{c}274.13 \\
341.13\end{array}$ & 343.24 & 345.40 \\
\hline 5 & 5-hydroxy-6,7,3', $4^{\prime}$-tetramethoxyflavone & 6.07 & $\begin{array}{l}275.13 \\
340.13\end{array}$ & 357.49 & 359.31 \\
\hline 6 & Unidentified & 7.08 & 274.13 & - & 301.36 \\
\hline
\end{tabular}

(-) protonated species not detected.

and reverse primer sequences for $\mathrm{Zn}-\mathrm{SOD}, \mathrm{Mn}-\mathrm{SOD}, \mathrm{CAT}$, glutathione peroxidase (GPx), and gamma-glutamylcysteine $(\delta$-GCS) were obtained from published nucleotide sequences [29]. The reactions were performed using the ABI Prism 7300 Sequence Detector (Applied Biosystems) under the following conditions: $50^{\circ} \mathrm{C}$ for $2 \mathrm{~min}, 95^{\circ} \mathrm{C}$ for $10 \mathrm{~min}$ and 40 cycles of $95^{\circ} \mathrm{C}$ for $15 \mathrm{~s}$, and $60^{\circ} \mathrm{C}$ for $1 \mathrm{~min}$.

The specificity of the products obtained was confirmed by analysis of the dissociation curves of the amplified product. As an internal control, the expression of the housekeeping gene $18 \mathrm{~S}$ was used. The data obtained were analyzed using the comparative $\mathrm{C}_{\mathrm{T}}$ method. All analyses were performed in triplicate.

2.12. Histological Evaluation. Liver fragments not exceeding $4 \mathrm{~mm}$ in diameter were fixed in 10\% formaldehyde solution and then dehydrated, diaphanized, and embedded in paraffin. Paraffin sections of approximately $4 \mu \mathrm{m}$ were obtained by sectioning embedded fragments on a rotary microtome. The sections were mounted on cleaned and degreased glass slides. The slides were stained with hematoxylin and eosin for visualization of histological damage.

2.13. Statistical Analysis. The data are expressed as the mean \pm standard deviation (SD). All data were subjected to a normality test. After determining that the data were normally distributed, we chose to use Student's $t$ test. A $P$ value $<0.05$ was considered significant. The tests were performed using GraphPad Prism version 4.00 for Windows (San Diego, CA, USA).

\section{Results}

3.1. LC-DAD-ESI-MS Analysis of Hydroethanolic Extract. In hydroethanolic extract of $B$. trimera we identify five flavonoids by LC-DAD-ESI-MS obtained of chromatogram in LC-DAD, as shown in Table 1.

3.2. In Vitro Assays: Toxicity of the Hydroethanolic Extract of B. trimera in Liver Cells (HEPG2). After incubation for
TABle 2: The toxicity of the hydroethanolic extract of $B$. trimera on hepatic cells (HEP G2) and viability of cells treated with the extract. The data are expressed as a percentage. HepG2 cells were incubated in the absence of B. trimera extract, and Hep G2 + Cq cells correspond to the hepatic cell culture incubated with $B$. trimera extract.

\begin{tabular}{lcccc}
\hline \multirow{2}{*}{ Strain } & \multicolumn{2}{c}{1 hour } & \multicolumn{2}{c}{24 hours } \\
& Viability & Toxicity & Viability & Toxicity \\
\hline HEP G2 & $100 \%$ & $0 \%$ & $100 \%$ & $0 \%$ \\
HEP G2 + Cq & $89.0 \%$ & $11.0 \%$ & $98.6 \%$ & $1.4 \%$ \\
\hline
\end{tabular}

1 and 24 hours (Table 2), it was observed that cells treated with the extract maintained high viability of $89.0 \%$ and $98.6 \%$, respectively, without exhibiting significant toxicity.

3.3. In Vivo Assays: Effect of B. trimera on Biomarkers of Hepatocellular Damage. Figure 3 shows the activity of serum transaminases in the different treatment groups. The ALT and AST transaminases were significantly enhanced $(P<0.05)$ by 9.8- and 6.3-fold, respectively, in APAP-intoxicated animals. Treatment with $B$. trimera significantly inhibited the elevation of the activity of serum transaminases ALT and AST, which was found to be 5.0- and 3.6-fold lower than that in the APAPintoxicated animals, respectively.

3.4. Effect of B. trimera on APAP-Induced Oxidative Damage. We evaluated the oxidative damage to proteins and lipids by measuring oxidative stress markers in hepatic tissue. Specifically, we analyzed carbonylated protein and TBARS in this tissue. The results shown in Figure 4 indicate a significant increase in the concentration of carbonylated protein in the livers of animals intoxicated with APAP compared to the nonintoxicated control group. However, treatment of APAPintoxicated rats with $B$. trimera resulted in the reduction of hepatic carbonylated protein concentration compared to the untreated B. trimera group. Moreover, we observed increased lipid peroxidation in rats intoxicated with APAP compared to nonintoxicated animals, and B. trimera treatment was also capable of reducing hepatic lipid peroxidation compared to 
the untreated group. Thus, these results demonstrate that treatment with $B$. trimera is capable of minimizing oxidative damage.

3.5. Effect of B. trimera on Antioxidant Status. To investigate the involvement of antioxidant enzymes in mediating the radical-scavenging activity of $B$. trimera, the mRNA levels and activities of intracellular antioxidant enzymes were measured in the different groups. The mRNA levels and activities of SOD and CAT are shown in Figure 5.

SOD and CAT function coordinately to remove superoxide radicals from the cellular system. The APAP-intoxicated group showed an increase in Zn-SOD (Figure 5(a)) and MnSOD (Figure 5(b)) expression compared to control animals. This increase in the expression of different isoforms of SOD was accompanied by an increase in the total activity of this enzyme in the group intoxicated with APAP (Figure 5(d)) $(0.33 \pm 0.07$ units $/ \mathrm{mg}$ protein) compared to the control (0.24 \pm 0.036 units/mg protein). In the APAP-intoxicated group treated with $B$. trimera, the mRNA level and activity were significantly lower than their respective control (APAP group). In this study, the mRNA levels and activity of catalase decreased significantly $(P<0.05)$ in the APAP-treated rats, and this decrease in expression and activity was prevented in the group intoxicated with APAP and treated with $B$. trimera.

Figure 6 shows that there was a significant increase in $\delta$ GCS (Figure 6(a)) gene expression in the livers of animals intoxicated with APAP. Treatment with $B$. trimera was able to reverse this profile, decreasing the expression of $\delta$-GCS. Despite the increased expression of $\delta$-GCS, there was a decrease in the concentration of total glutathione in the livers of animals intoxicated with APAP. However, treatment with B. trimera was able to reverse this decrease (Figure 6(b)).

The results in Figure 7 show a decrease in the mRNA and enzyme activity of GPx (Figures 7(a) and 7(b)) and in the activity of the enzyme GR (Figure $7(\mathrm{c})$ ) in the livers of APAPintoxicated rats compared to control rats. B. trimera was able to increase the mRNA levels of GPx and GR activities. No change was observed in the activity of GPx and GR in the livers of rats that received only the extract.

3.6. Histopathology. Microscopic observations revealed normal histology with regular morphology of the liver tissue in the control (Figure 8(a)) and B. trimera groups (Figure 8(b)). In the APAP-intoxicated group (Figure 8(c)), cellular damage was visible in the form of hydropic degeneration, inflammation, and hemorrhage. The $B$. trimera treatment (Figure $8(d)$ ) considerably improved the liver morphology in comparison to the APAP-intoxicated rats.

\section{Discussion}

Research aiming to propose new strategies of therapeutic intervention increasingly includes the use of plant extracts and other natural products. Studies carried out in our lab have demonstrated the beneficial potential of the hydroalcoholic extract of B. trimera on the toxicity induced by APAP [30]. In the peripheral neutrophils of rats intoxicated with this drug, the extract was able to regulate the production of reactive oxygen species (ROS) and reactive nitrogen species (RNS). Williams et al. (2014) studied the activation of neutrophils during APAP-induced hepatotoxicity and demonstrated that ROS generation mediated by NADPH oxidase is not a critical event during liver injury caused by this drug. However, they also found that neutrophils present in peripheral blood are activated after administration of APAP. Although the contribution of inflammatory cells to the hepatic damage induced by APAP is still controversial [31], the innate immune response and the production of reactive species from different sources are correlated with many diseases that affect the liver. For example, neutrophils are associated with hepatic injury during ischemia, endotoxemia, and obstructive cholestasis in animal models $[9,32]$.

The pharmacological effect of the hydroalcoholic extract of B. trimera was investigated in our lab. A LC-DAD-ESIMS analysis of the hydroalcoholic extract revealed presence of flavonoids, flavone, and glucosides of flavone compounds (Figure 2).

Many studies have found that the hepatotoxicity induced by APAP is the result of oxidative stress, which causes alterations in mitochondrial proteins due to a depletion of glutathione, leading to an inhibition of cellular respiration with consequent cell death [33]. Because of the biological effects described for flavonoids found in the extract, this study was conducted to investigate the effect of $B$. trimera in the modulation of oxidative stress and to evaluate the preventive effect of $B$. trimera in acetaminophen-induced liver damage.

Despite the lack of studies related to the toxicity of $B$. trimera, histopathological alterations have recently been found in the livers of pregnant rats treated with a hydroethanolic extract of the plant [22]; moreover, Rodrigues et al. [21] showed that $B$. trimera produced some genotoxic and mutagenic effects after consumption of high doses of the extract.

In this context, to analyze its toxicity, hepatic HEP G2 cells were incubated in the presence or absence of $B$. trimera extract to obtain the cellular viability/toxicity relationship. After the assays, it was observed that the hydroalcoholic extract did not present significant toxicity, and cells maintained viability of $89.0 \%$ and $98.6 \%$ after incubation periods of $1 \mathrm{~h}$ and $24 \mathrm{~h}$, respectively. These values show no statistical difference.

Based on these results, we wondered whether the $B$. trimera extract would be able to reverse the hepatotoxicity induced by APAP. To do this, initially, we analyzed the activity of the hepatic enzymes AST and ALT. Both AST and ALT are intracellular enzymes present in large amounts in the cytoplasm of hepatocytes. Lesions or destruction of hepatic cells releases these aminotransferases into the circulation [34]. Our study showed that APAP caused a significant increase in the activity of ALT and AST. However, pretreatment with the plant extract restored this activity to values similar to those of the control. High doses of APAP have been associated with higher activity of ALT and AST $[35,36]$. The ability of $B$. trimera to prevent the increase in the activity of these enzymes makes it evident that its chemical constituents exert an important hepatoprotective activity. 
<smiles>COc1ccc(-c2cc(=O)c3c(O)cc(OC4OCC(O)C(O)C4OC4OCC(O)(CO)C4O)cc3o2)cc1O</smiles><smiles>O=c1c(O)c(-c2ccc(O)c(O)c2)oc2cc(O)cc(O)c12</smiles><smiles>COc1cc(O)c2c(=O)cc(-c3ccc(OC)c(O)c3)oc2c1</smiles><smiles>COc1ccc(-c2cc(=O)c3c(O)c(OC)c(OC)cc3o2)cc1O</smiles><smiles>COc1ccc(-c2cc(=O)c3c(O)c(OC)c(OC)cc3o2)cc1OC</smiles>

FIGURE 2: Identified compounds in hydroethanolic extract of B. trimera by LC-DAD-ESI-MS.
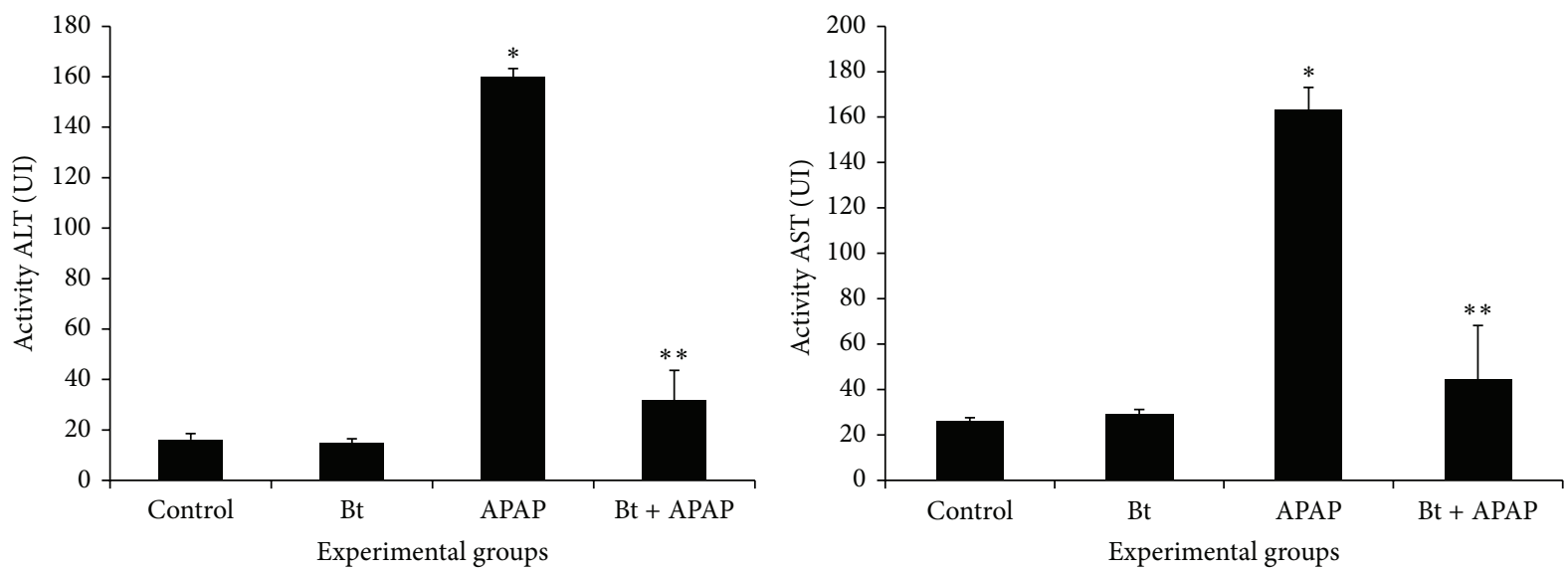

FIGURE 3: Effect of $B$. trimera hydroethanolic extract on ALT and AST activity in serum of rats $24 \mathrm{~h}$ after treatment with APAP. The rats were treated with $600 \mathrm{mg} / \mathrm{kg} \mathrm{B}$. trimera $1 \mathrm{~h}$ before administration of $835 \mathrm{mg} / \mathrm{kg}$ APAP. The data are expressed as the mean $\pm \mathrm{SD}(n=8)$. ${ }^{*} P<0.05$ compared to the control, ${ }^{* *} \mathrm{P}<0.05$ compared to APAP.

In addition to analyzing the activities of these hepatic enzymes, the levels of products of oxidative stress have also been described to demonstrate the occurrence of oxidative damage [37]. Among these products are substances reactive to thiobarbituric acid (TBAR) and carbonylated proteins. The levels of these substances are used as markers of redox balance in terms of lipid peroxidation and protein oxidation, respectively, in hepatic cells [38].

In our results, animals intoxicated with APAP presented high levels of carbonylated proteins and TBAR. However, pretreatment with $B$. trimera extract was able to reduce the levels of these compounds to values similar to those of their respective controls. It is known that plants, because they present antioxidant constituents, are efficient in reducing the lipid peroxidation and protein oxidation induced by APAP $[39,40]$. One of the explanations for this phenomenon is that these phytochemicals are able to minimize the oxidative stress in the livers of animals intoxicated with high doses of this drug [41].

Because B. trimera has shown such a significant effect on the development of oxidative stress products, we evaluated its effect on the expression and activity of antioxidant enzymes. 

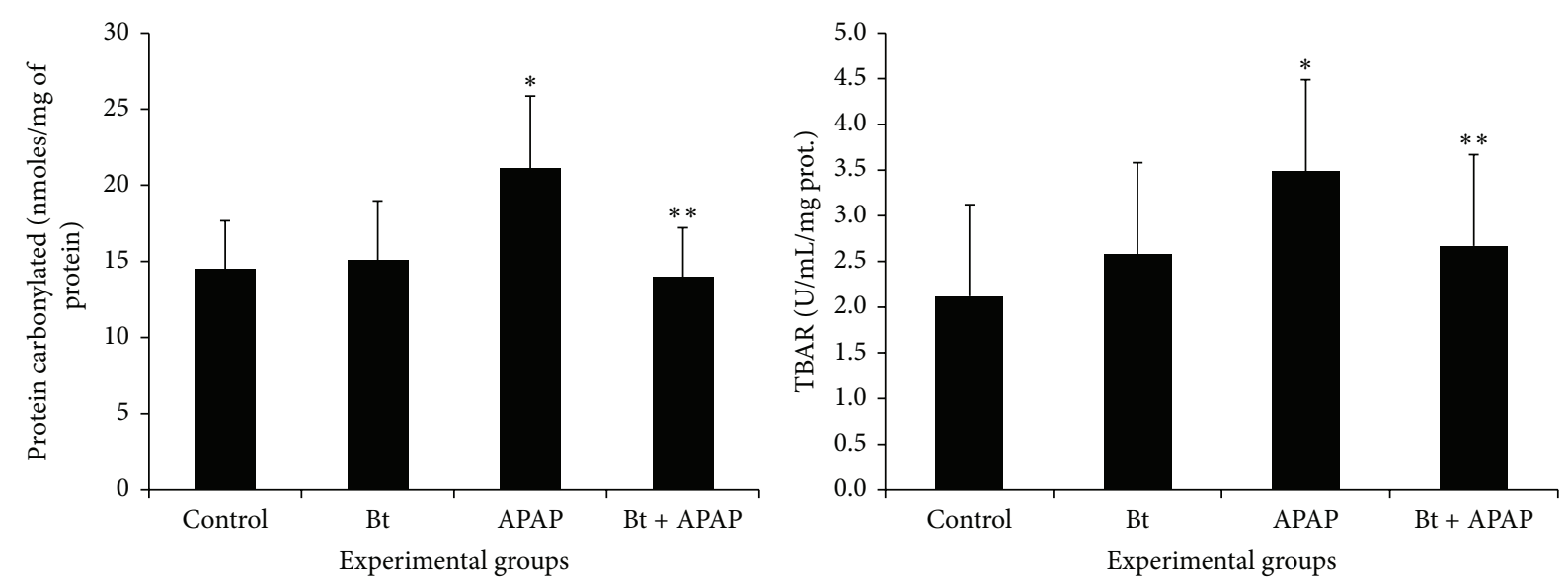

FIGURE 4: Effect of B. trimera hydroethanolic extract on the level of carbonylated protein and TBARS in the livers of rats $24 \mathrm{~h}$ after treatment with APAP. The rats were treated with $600 \mathrm{mg} / \mathrm{kg} \mathrm{B}$. trimera $1 \mathrm{~h}$ before administration of $835 \mathrm{mg} / \mathrm{kg}$ APAP. The data are expressed as the mean $\pm \mathrm{SD}(n=8) .{ }^{*} P<0.05$ compared to the control, ${ }^{* *} P<0.05$ compared to APAP.

The protective action of several herbal medicines and their active constituents occurs through antioxidant enzymes (e.g., SOD, CAT, GPx, and GR), which maintain the prooxidant/antioxidant balance in the body. To eliminate ROS from the cellular system, SOD and CAT function coordinately to remove superoxide radicals [1]. Our results showed that the livers of animals intoxicated with APAP presented higher expression of the SOD-Zn and SOD-Mn isoforms. However, treatment with $B$. trimera was able to regulate this expression to values similar to those of the livers of the control animals. This increase in gene expression was followed by a higher SOD enzymatic activity. Although SOD is an antioxidant enzyme, some studies have suggested that its overexpression is in fact harmful to cells [42]. The toxic effect of ROS that has been observed in many cells overexpressing SOD has been linked to elevated levels of $\mathrm{H}_{2} \mathrm{O}_{2}$ and oxidative damage accompanying hydroxyl radical formation [43]. The implication is that SOD upregulation results in high $\mathrm{H}_{2} \mathrm{O}_{2}$ turnover.

Our results showed that the liver of animals intoxicated with APAP presented lower expression of CAT. However, $B$. trimera treatment was able to regulate this expression to values similar to those of the livers of control animals. This decrease in gene expression was followed by a lower CAT enzymatic activity. CAT activity was found to be significantly decreased after a toxic APAP dose [44]. Our results were similar in that CAT activity was significantly diminished following toxic APAP insult. This would allow for the accumulation of ROS and hydrogen peroxide, which can exacerbate the hepatocellular damage initiated by NAPQI. Treatment with the B. trimera extract abrogated the effect of APAP and induced an increase in CAT activity. This suggests the involvement of their antioxidant constituents in facilitating the rapid and efficient consumption of reactive oxygen species generated by APAP-mediated P450 bioactivation [36].

Glutathione (GSH/GSSG) is regarded as the main redox buffer in cells. Glutathione plays an important role in the removal of ROS and protects the thiols in biomacromolecules
[45]. Under normal conditions, glutathione is mainly found in its reduced form (GSH) and in much smaller amounts in its oxidized form (GSSG) [46]. Depletion of glutathione has been associated with enhanced toxicity to chemicals, including APAP [47]. The results of our present study showed that the livers of animals intoxicated with APAP, even presenting high $\delta$-GCS activity, presented levels of total glutathione less than those of the livers of control animals. However, pretreatment with $B$. trimera increased the level of total glutathione in APAP-treated animals. These results suggested that $B$. trimera could exert its hepatoprotective and radical-scavenging activities by preventing the formation of free radicals originating from APAP metabolism as well as peroxidation products and enhance the antioxidant defense system. This hypothesis is supported by recent findings that demonstrate that the antioxidant and hepatoprotective activities of extract might be mediated through augmentation of antioxidant defenses and increase in free radical inhibition due to the presence of important antioxidative factors [48].

The antioxidant effects of glutathione are directly related to GPx and GR, which are key enzymes in the maintenance of redox homeostasis via protecting cells from free radicalgenerated toxicity [1]. Our results show a decrease in the mRNA and enzyme activity of GPx and in the activity of the enzyme GR in the livers of rats $24 \mathrm{~h}$ after treatment with APAP compared to control rats. GR is an enzyme that plays a critical role in oxidative stress by APAP; a decrease in its activity will lead to interruption of the cycling between GSSG and GSH and, thus, to a shortage of GSH. Although the impairment of GR activity by APAP is not well understood, at least two hypotheses have been put forth to explain this occurrence, one invoking direct action of ROS or toxic aldehydes and another ascribing the effect to the NAPQIGSH conjugate that forms in the presence of glutathione Stransferase [49].

The low activity of GPx is one of the early consequences of a disturbance of the prooxidant/antioxidant balance in favor of the former [50]. Inhibition of GPx increases the 


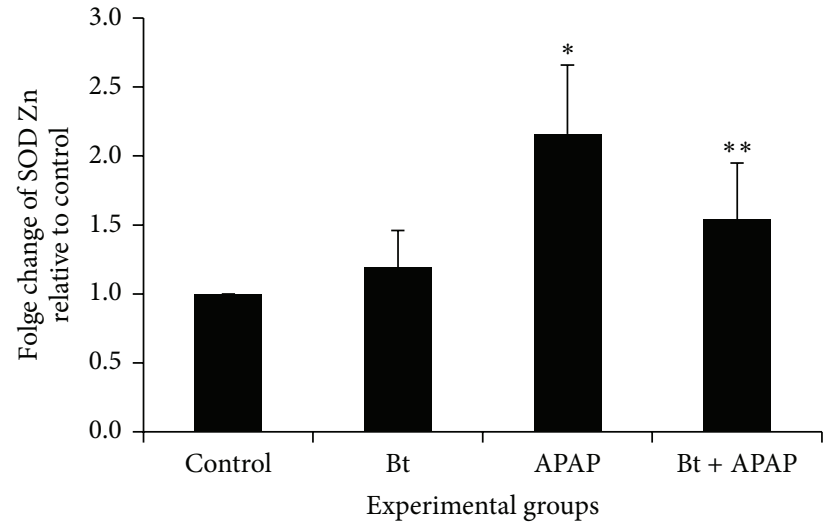

(a)

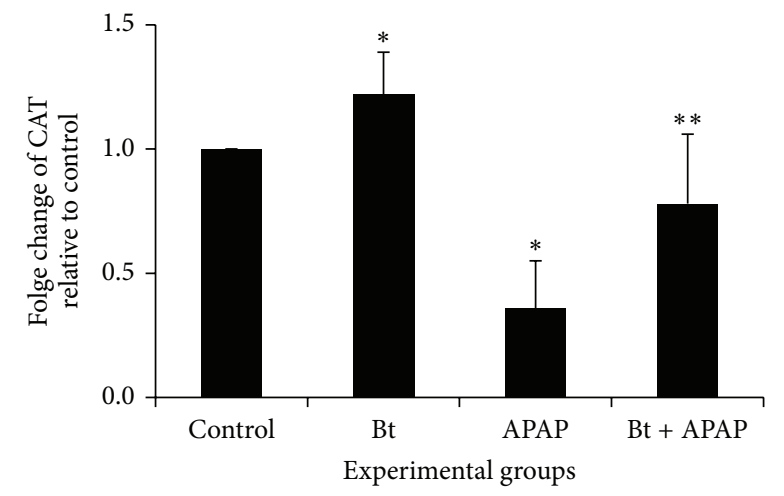

(c)

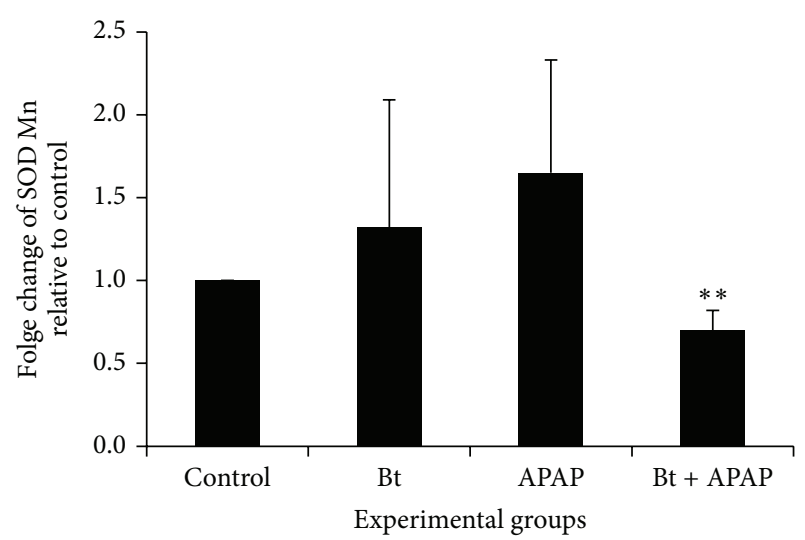

(b)

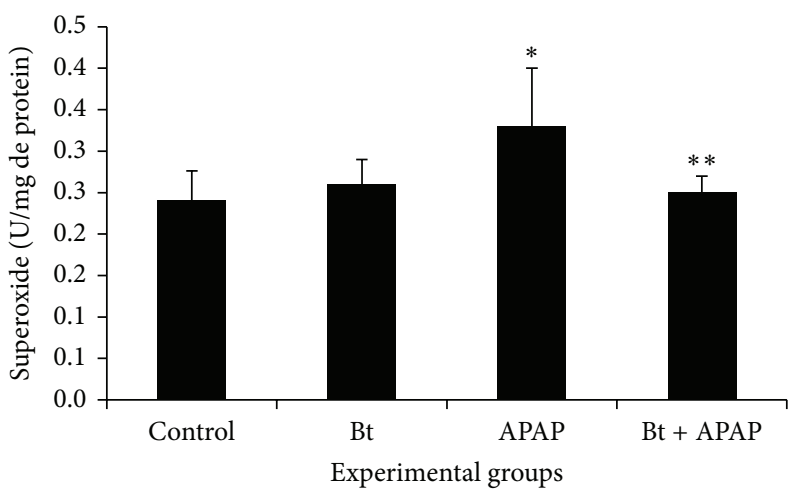

(d)

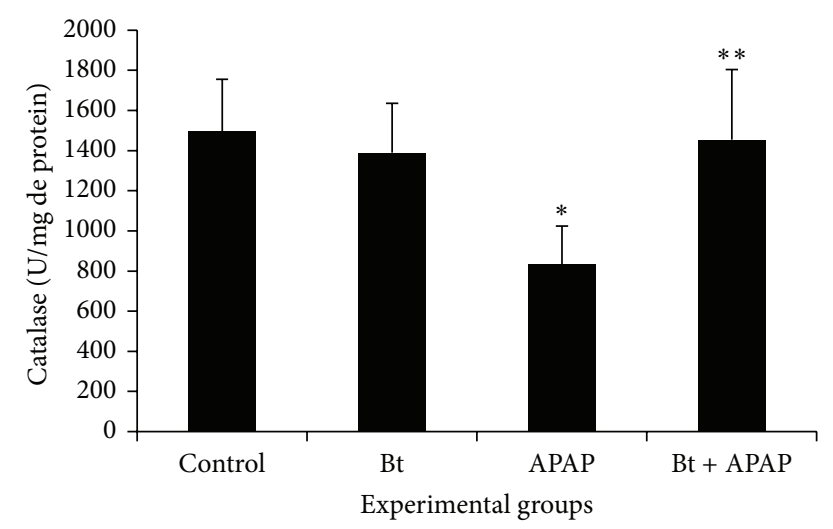

(e)

FIGURE 5: Effect of B. trimera hydroethanolic extract on the mRNA expression of the enzymes Zn-SOD (a), Mn-SOD (b), and CAT (c) and on the SOD (d) and CAT (e) activity in the livers of rats $24 \mathrm{~h}$ after treatment with APAP. The rats were treated with $600 \mathrm{mg} / \mathrm{kg} \mathrm{B.} \mathrm{trimera} 1 \mathrm{~h}$ before administration of $835 \mathrm{mg} / \mathrm{kg}$ APAP. The data are expressed as the mean $\pm \mathrm{SD}(n=8) .{ }^{*} P<0.05$ compared to the control, ${ }^{* *} P<0.05$ compared to APAP.

susceptibility of hepatocytes to paracetamol toxicity, indicating that a component of paracetamol's toxic effect involves the formation of species that are detoxified by GPx enzymes [51]. Flavonoids have been demonstrated to protect against paracetamol toxicity by inhibiting lipid peroxidation and increasing glutathione concentration [52]. Hence, the ability of plant extracts to restore the loss of GPx activity is most likely due to the presence of flavonoids. The striking increase in the GPx activity of the B. trimera-treated group compared with the group that received only APAP may be a result of the presence of quercetin and flavones in addition to other antioxidants in the plant.

Due to the inhibition of GPx, this study concluded that hepatic cell injury was the result of an increase in the steadystate level of $\mathrm{H}_{2} \mathrm{O}_{2}$ and hydroperoxides [53]. While this suggestion implies that oxidative stress is the determining factor of GSH depletion, there is also evidence to support the opposite order of events; namely, ROS production follows 


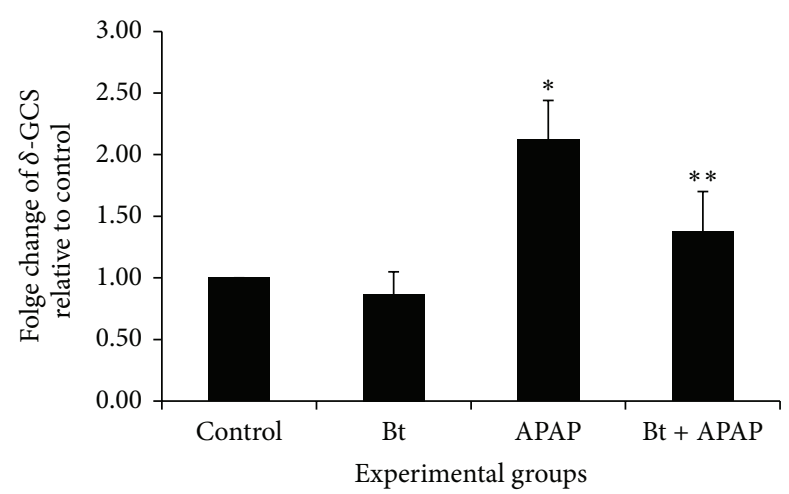

(a)

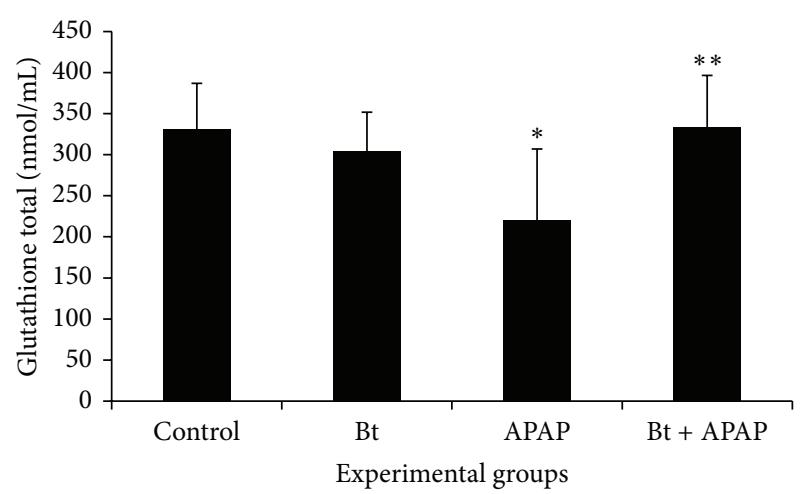

(b)

FIGURE 6: Effect of B. trimera hydroethanolic extract on mRNA expression of $\delta$-GCS (a) and on total glutathione in rat livers $24 \mathrm{~h}$ after treatment with APAP (b). The rats were treated with $600 \mathrm{mg} / \mathrm{kg}$ B. trimera $1 \mathrm{~h}$ before administration of $835 \mathrm{mg} / \mathrm{kg}$ APAP. The data are expressed as the mean $\pm \mathrm{SD}(n=8) .{ }^{*} \mathrm{P}<0.05$ compared to the control, ${ }^{* *} \mathrm{P}<0.05$ compared to APAP.

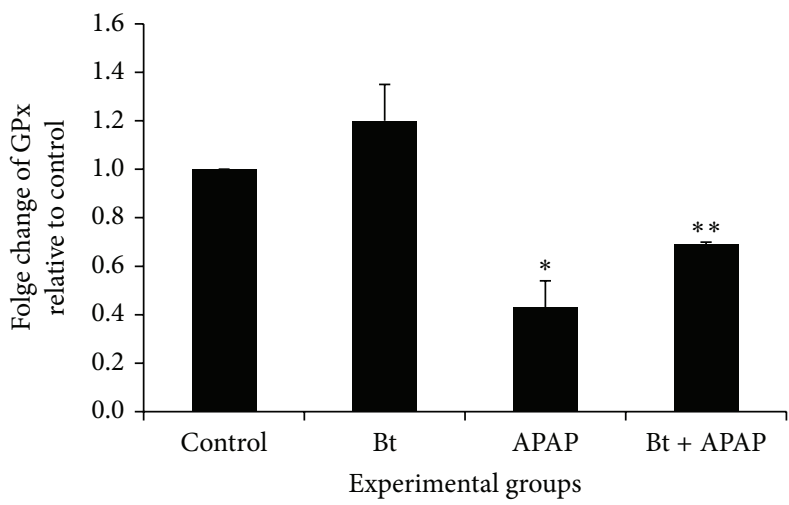

(a)

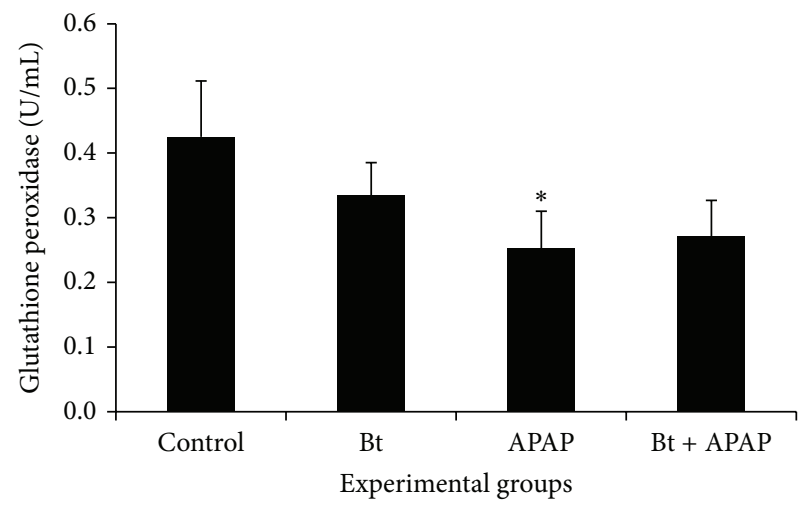

(b)

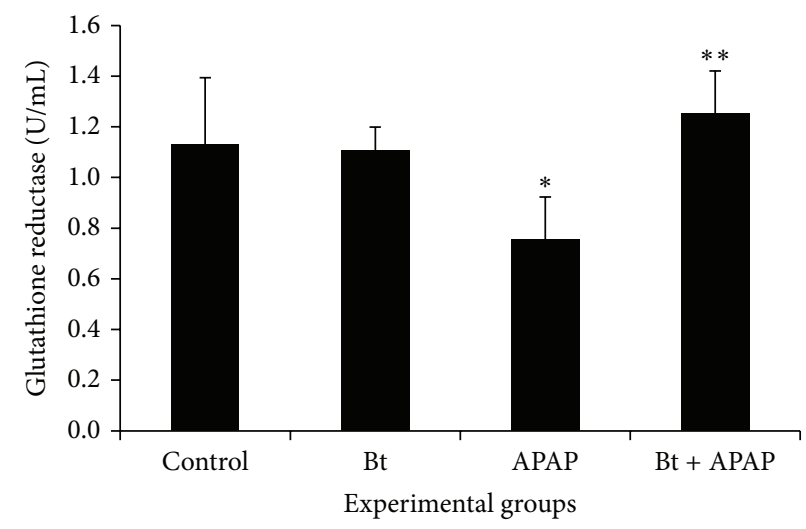

(c)

FIGURE 7: Effect of B. trimera hydroethanolic extract on mRNA expression of GPx (a) and on the activity of glutathione peroxidase (GPx) (b) and activity of glutathione reductase (c) in the livers of rats $24 \mathrm{~h}$ after treatment with APAP. The rats were treated with $600 \mathrm{mg} / \mathrm{kg} B$. trimera $1 \mathrm{~h}$ before administration of $835 \mathrm{mg} / \mathrm{kg}$ APAP. The data are expressed as the mean $\pm \mathrm{SD}(n=8) .{ }^{*} P<0.05$ compared to the control, ${ }^{* *} P<0.05$ compared to APAP.

the depletion of GSH [54]. In other words, the levels of antioxidant enzymes, if analyzed concomitantly, allow us to infer that the animals intoxicated with APAP presented high concentration of hepatic $\mathrm{H}_{2} \mathrm{O}_{2}$, given that high SOD activity leads to a high production of ERO, and low CAT and GPx activities prevent the $\mathrm{H}_{2} \mathrm{O}_{2}$ generated from being neutralized.

To confirm the hepatoprotective effect of B. trimera extract against the damages caused by APAP, histopathological 


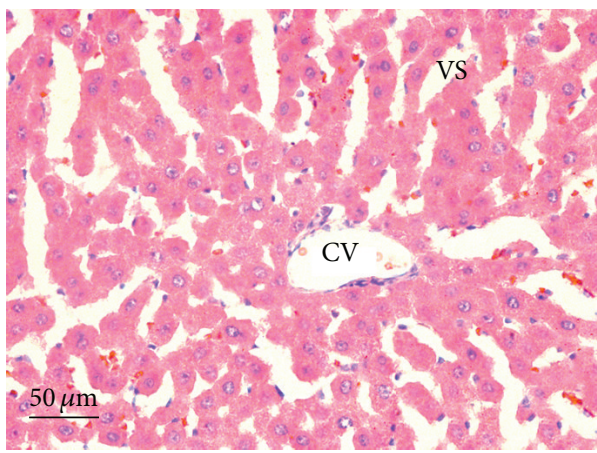

(a)

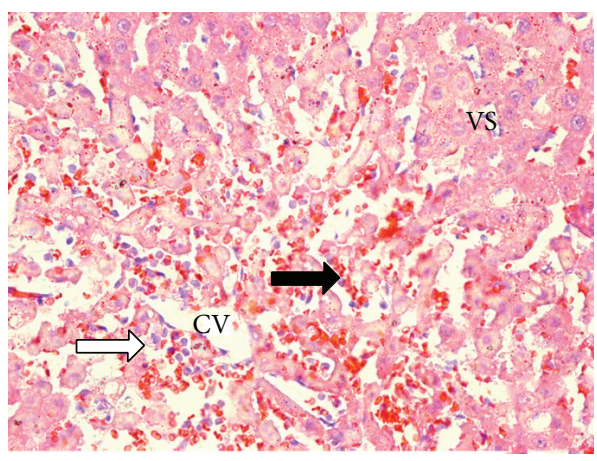

(c)

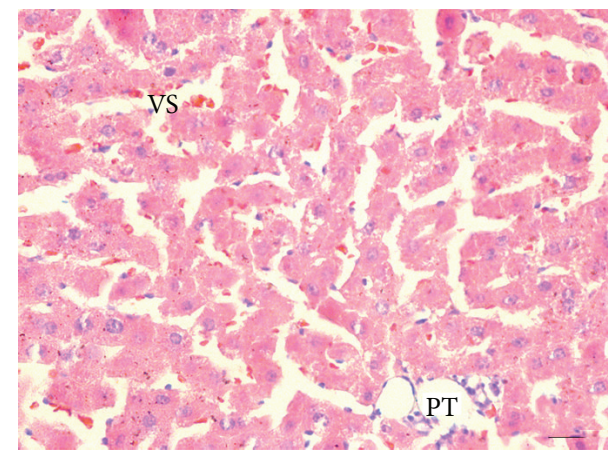

(b)

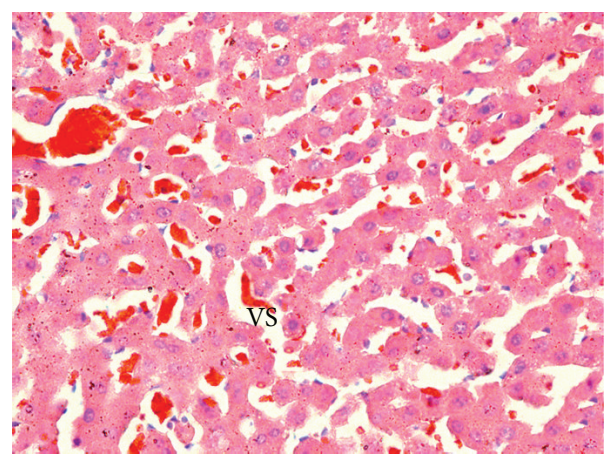

(d)

FIgURE 8: Sections of the livers of rats 24 hours after administration of PBS (a), extract of B. trimera (b), APAP (c), and B. trimera extract and APAP (d), showing (a) normal rats liver with no significant hepatic abnormalities; (b) normal rat liver with no significant hepatic abnormalities; (c) hepatic lesions, hydropic degeneration, inflammation (white arrow) and hemorrhage (black arrow); (d) well-formed polygonal hepatocytes and relatively reduced hydropic degeneration. CV: central vein; VS: venous sinuses; PT: portal triads; liver sections were stained with $\mathrm{H} \& \mathrm{E}(400 \mathrm{x})$.

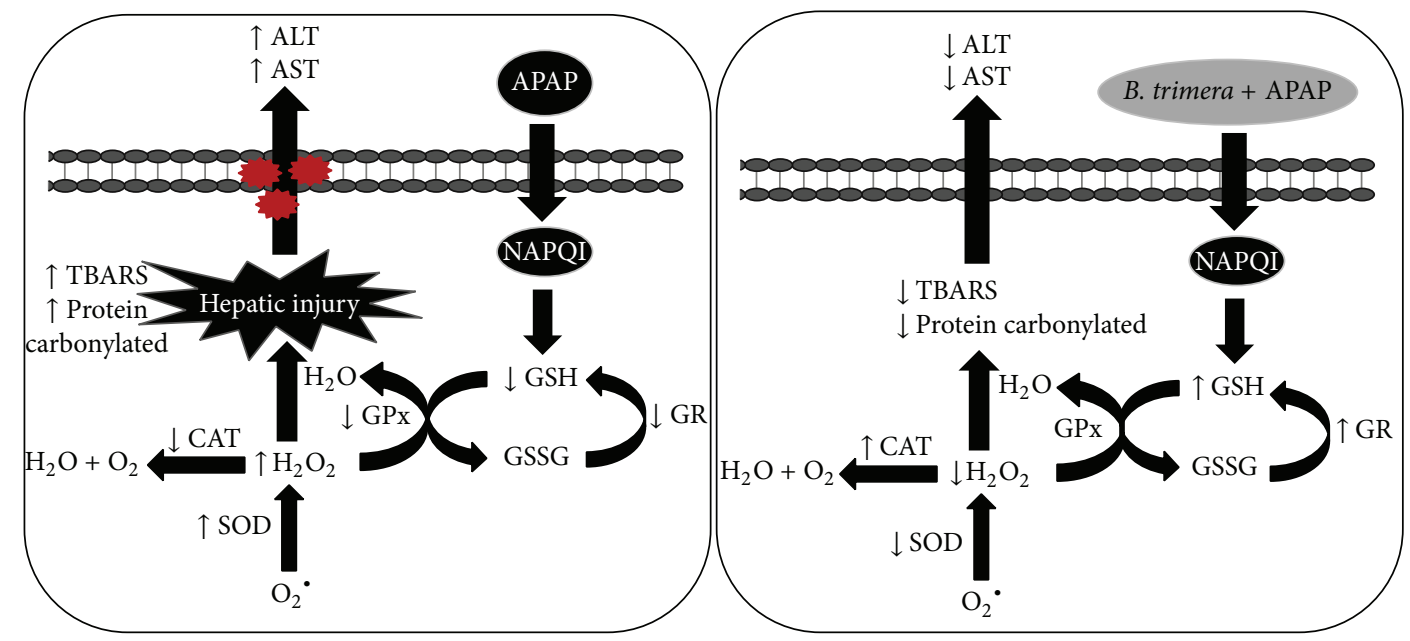

FIGURE 9: A schematic diagram showing the protective effect of B. trimera in acetaminophen-induced toxicity. APAP causes excessive oxidative stress and decreases the activity of antioxidant enzymes, such as GR, GPx, and CAT, and increases the activity of SOD, presumably resulting in the elevation of $\mathrm{H}_{2} \mathrm{O}_{2}$. The disturbance of the oxidant/antioxidant balance causes oxidative stress of the cellular system and results in hepatic injury, specifically the elevation of the ALT and AST. The administration of B. trimera was found to maintain the oxidant/antioxidant balance during APAP treatment, resulting in the prevention of cell damage. 
analyses were performed. APAP-intoxicated animals treated with the $B$. trimera extract had improved histopathology compared to the APAP-intoxicated group without treatment.

In conclusion, the present study demonstrated that the hydroalcoholic extract of $B$. trimera has a hepatoprotective effect against APAP-induced hepatotoxicity in rats. The enhanced levels of antioxidant enzymes and reduced amount of peroxidation products are suggested to be the major mechanisms by which the $B$. trimera hydroalcoholic extract prevents the development of liver damage induced by APAP (Figure 9). Furthermore, a recent study published by our research group shows that the extract of $B$. trimera is also capable of modulating the activity of NADPH oxidase in peripheral neutrophils of rats intoxicated with APAP [55].

\section{Conflict of Interests}

The authors declare no conflict of interests.

\section{Acknowledgments}

This research was supported by the Fundação de Amparo à Pesquisa do Estado de Minas Gerais (FAPEMIG), Conselho Nacional de Desenvolvimento Científico e Tecnológico (CNPq), Coordenação de Aperfeiçoamento de Pessoal de Nível superior (CAPES-PNPD), Centro Federal de Educação Tecnológica de Minas Gerais (CEFET-MG), and Universidade Federal de Ouro Preto (UFOP), Brazil. The authors are grateful to Dr. Maria Terezinha Bahia of the Laboratory of Doença de Chagas, Ouro Preto, MG, Brazil, for the use of the ABI Prism 7300 Sequence Detector (Applied Biosystems).

\section{References}

[1] A. Kumari and P. Kakkar, "Lupeol prevents acetaminopheninduced in vivo hepatotoxicity by altering the Bax/Bcl-2 and oxidative stress-mediated mitochondrial signaling cascade," Life Sciences, vol. 90, no. 15-16, pp. 561-570, 2012.

[2] W. M. Lee, "Drug-induced hepatotoxicity," The New England Journal of Medicine, vol. 349, no. 5, pp. 474-485, 2003.

[3] W. C. Maddrey, "Drug induced hepatotoxicity," Journal of Clinical Gastroenterology, vol. 39, pp. 883-889, 2005.

[4] P. J. Amar and E. R. Schiff, "Acetaminophen safety and hepatotoxicity-where do we go from here?" Expert Opinion on Drug Safety, vol. 6, no. 4, pp. 341-355, 2007.

[5] O. Moling, E. Cairon, G. Rimenti, F. Rizza, R. Pristerá, and P. Mian, "Severe hepatotoxicity after therapeutic doses of acetaminophen," Clinical Therapeutics, vol. 28, no. 5, pp. 755$760,2006$.

[6] W. M. Lee, "Acetaminophen and the U.S. acute liver failure study group: lowering the risks of hepatic failure," Hepatology, vol. 40, no. 1, pp. 6-9, 2004.

[7] O. W. Morgan, C. Griffiths, and A. Majeed, "Interrupted timeseries analysis of regulations to reduce paracetamol (acetaminophen) poisoning," PLoS Medicine, vol. 4, no. 4, article e105, 2007.

[8] G. Dai, L. He, N. Chou, and J.-J. Y. Wan, "Acetaminophen metabolism does not contribute to gender difference in its hepatotoxicity in mouse," Toxicological Sciences, vol. 92, no. 1, pp. 33-41, 2006.

[9] L. P. James, P. R. Mayeux, and J. A. Hinson, "Acetaminopheninduced hepatotoxicity," Drug Metabolism and Disposition, vol. 31, no. 12, pp. 1499-1506, 2003.

[10] H. Jaeschke, "Molecular mechanisms of hepatic ischemiareperfusion injury and preconditioning," The American Journal of Physiology-Gastrointestinal and Liver Physiology, vol. 284, no. 1, pp. G15-G26, 2003.

[11] H. S. Oz, C. J. McClain, H. T. Nagasawa, M. B. Ray, W. J. S. de Villiers, and T. S. Chen, "Diverse antioxidants protect against acetaminophen hepatotoxicity," Journal of Biochemical and Molecular Toxicology, vol. 18, no. 6, pp. 361-368, 2004.

[12] H. S. Oz and T. S. Chen, "Green-tea polyphenols downregulate cyclooxygenase and Bcl-2 activity in acetaminophen-induced hepatotoxicity," Digestive Diseases and Sciences, vol. 53, no. 11, pp. 2980-2988, 2008.

[13] C. Girish, B. C. Koner, S. Jayanthi, K. Ramachandra Rao, B. Rajesh, and S. C. Pradhan, "Hepatoprotective activity of picroliv, curcumin and ellagic acid compared to silymarin on paracetamol induced liver toxicity in mice," Fundamental and Clinical Pharmacology, vol. 23, no. 6, pp. 735-745, 2009.

[14] S. D. Ray, D. Zinkovsky, and E. Bulku, "Prevention of drug induced programmed andunprogrammed cell death by citrus flavonoids," in Proceedings of the 228th ACS-Agriculture and Food "Botanical Health Effects of Citrus", ACS Symposium Series, chapter 11, American Chemical Society, 2006.

[15] Y.-J. Surh and H.-K. Na, "NF- $\kappa$ B and Nrf2 as prime molecular targets for chemoprevention and cytoprotection with anti-inflammatory and antioxidant phytochemicals," Genes and Nutrition, vol. 2, no. 4, pp. 313-317, 2008.

[16] C. Mitchell, M. A. Park, G. Zhang et al., "Extrinsic pathway- and cathepsin-dependent induction of mitochondrial dysfunction are essential for synergistic flavopiridol and vorinostat lethality in breast cancer cells," Molecular Cancer Therapeutics, vol. 6, no. 12, pp. 3101-3112, 2007.

[17] M. J. Abad and M. Bermejo, "Baccharis (Compositae): a review update," Arkivoc, vol. 7, pp. 76-96, 2007.

[18] L. G. Verdi, I. M. C. Brighente, and M. G. Pizzolatti, "Gênero Baccharis (Asteraceae): aspectos químicos, econômicos e biológicos," Quimica Nova, vol. 28, no. 1, pp. 85-94, 2005.

[19] R. Della-Loggia, A. Tubaro, S. Sosa, H. Becker, S. Saar, and O. Isaac, "The role of triterpenoids in the topical anti-inflammatory activity of Calendula officinalis flowers," Planta Medica, vol. 60, no. 6, pp. 516-520, 1994.

[20] T. Akihisa, K. Yasukawa, H. Oinuma et al., "Triterpene alcohols from the flowers of compositae and their anti- inflammatory effects," Phytochemistry, vol. 43, no. 6, pp. 1255-1260, 1996.

[21] C. R. F. Rodrigues, J. H. Dias, R. N. de Mello, M. F. Richter, J. N. Picada, and A. B. F. Ferraz, "Genotoxic and antigenotoxic properties of Baccharis trimera in mice," Journal of Ethnopharmacology, vol. 125, no. 1, pp. 97-101, 2009.

[22] S. R. M. Grance, M. A. Teixeira, R. S. Leite et al., "Baccharis trimera: effect on hematological and biochemical parameters and hepatorenal evaluation in pregnant rats," Journal of Ethnopharmacology, vol. 117, no. 1, pp. 28-33, 2008.

[23] F. C. Meotti, J. M. Rosa, P. S. Brocardo et al., "Protective effect of crude extract from Wedelia paludosa (Asteraceae) on the hepatotoxicity induced by paracetamol in mice," Journal of Pharmacy and Pharmacology, vol. 58, no. 1, pp. 137-142, 2006. 
[24] T. A. Ajith, U. Hema, and M. S. Aswathy, "Zingiber officinale Roscoe prevents acetaminophen-induced acute hepatotoxicity by enhancing hepatic antioxidant status," Food and Chemical Toxicology, vol. 45, no. 11, pp. 2267-2272, 2007.

[25] F. L. Yen, T. H. Wu, L. T. Lin, T. M. Cham, and C. C. Lin, "Nanoparticles formulation of Cuscuta chinensis prevents acetaminophen-induced hepatotoxicity in rats," Food and Chemical Toxicology, vol. 46, no. 5, pp. 1771-1777, 2008.

[26] J. A. Buege and S. D. Aust, "Microsomal lipid peroxidation," Methods in Enzymology, vol. 52, pp. 302-310, 1978.

[27] R. L. Levine, J. A. Williams, E. R. Stadtman, and E. Shacter, "Carbonyl assays for determination of oxidatively modified proteins," Methods in Enzymology, vol. 233, pp. 346-357, 1994.

[28] H. Aebi, "[13] Catalase in vitro," Methods in Enzymology, vol. 105, pp. 121-126, 1984.

[29] Q. Xiong, P. Xie, H. Li et al., "Acute effects of microcystins exposure on the transcription of antioxidant enzyme genes in three organs (liver, kidney, and testis) of male Wistar rats," Journal of Biochemical and Molecular Toxicology, vol. 24, no. 6, pp. 361-367, 2010.

[30] B. D. C. Pádua, L. D. Silva, J. V. Rossoni et al., "Antioxidant properties of Baccharis trimera in the neutrophils of Fisher rats," Journal of Ethnopharmacology, vol. 129, no. 3, pp. 381-386, 2010.

[31] H. Jaeschke, "Innate immunity and acetaminophen-induced liver injury: why so many controversies?" Hepatology, vol. 48, no. 3, pp. 699-701, 2008.

[32] H. Jaeschke and T. Hasegawa, "Role of neutrophils in acute inflammatory liver injury," Liver International, vol. 26, no. 8, pp. 912-919, 2006.

[33] H. Jaeschke, C. D. Williams, A. Ramachandran, and M. L. Bajt, "Acetaminophen hepatotoxicity and repair: the role of sterile inflammation and innate immunity," Liver International, vol. 32, no. 1, pp. 8-20, 2012.

[34] V. T. Motta, Bioquímica Clínica Para o Laboratório: Princípios e Interpretações, Editora Médica Missau, Caxias do Sul, Brazil, 2003.

[35] E. Kozer, S. Evans, J. Barr et al., "Glutathione, glutathionedependent enzymes and antioxidant status in erythrocytes from children treated with high-dose paracetamol," British Journal of Clinical Pharmacology, vol. 55, no. 3, pp. 234-240, 2003.

[36] M. T. Olaleye and B. T. J. Rocha, "Acetaminophen-induced liver damage in mice: effects of some medicinal plants on the oxidative defense system," Experimental and Toxicologic Pathology, vol. 59, no. 5, pp. 319-327, 2008.

[37] G. Perry, A. K. Raina, A. Nunomura, T. Wataya, L. M. Sayre, and M. A. Smith, "How important is oxidative damage? Lessons from Alzheimer's disease," Free Radical Biology and Medicine, vol. 28, no. 5, pp. 831-834, 2000.

[38] M. F. Beal, "Oxidatively modified proteins in aging and disease," Free Radical Biology \& Medicine, vol. 32, no. 9, pp. 797-803, 2002.

[39] T. H. Tseng, E. S. Kao, C. Y. Chu, F. P. Chou, H. W. Lin Wu, and C. J. Wang, "Protective effects of dried flower extracts of Hibiscus sabdariffa L. against oxidative stress in rat primary hepatocytes," Food and Chemical Toxicology, vol. 35, no. 12, pp.1159-1164, 1997.

[40] P. Picerno, G. Autore, S. Marzocco, M. Meloni, R. Sanogo, and R. P. Aquino, "Anti-inflammatory activity of verminoside from Kigelia africana and evaluation of cutaneous irritation in cell cultures and reconstituted human epidermis," Journal of Natural Products, vol. 68, no. 11, pp. 1610-1614, 2005.
[41] S. D. Ray, N. Patel, N. Shah, A. Nagori, A. Naqvi, and S. J. Stohs, "Pre-exposure to a novel nutritional mixture containing a series of phytochemicals prevents acetaminophen-induced programmed and unprogrammed cell deaths by enhancing BCL-XL expression and minimizing oxidative stress in the liver," Molecular and Cellular Biochemistry, vol. 293, no. 1-2, pp. 119-136, 2006.

[42] R. Gardner, A. Salvador, and P. Moradas-Ferreira, "Why does SOD overexpression sometimes enhance, sometimes decrease, hydrogen peroxide production? A minimalist explanation," Free Radical Biology \& Medicine, vol. 32, no. 12, pp. 1351-1357, 2002.

[43] J. B. de Haan, F. Cristiano, R. Iannello, C. Bladier, M. J. Kelner, and I. Kola, "Elevation in the ratio of $\mathrm{Cu} / \mathrm{Zn}$-superoxide dismutase to glutathione peroxidase activity induces features of cellular senescence and this effect is mediated by hydrogen peroxide," Human Molecular Genetics, vol. 5, no. 2, pp. 283-292, 1996.

[44] R. Bhattacharjee and C. S. Parames, "The protein fraction of Phyllanthus niruri plays a protective role against acetaminophen induced hepatic disorder via its antioxidant properties," Phytotherapy Research, vol. 20, no. 7, pp. 595-601, 2006.

[45] A. Pastore, G. Federici, E. Bertini, and F. Piemonte, "Analysis of glutathione: implication in redox and detoxification," Clinica Chimica Acta, vol. 333, no. 1-2, pp. 19-39, 2003.

[46] C. Cereser, J. Guichard, J. Drai et al., "Quantitation of reduced and total glutathione at the femtomole level by high-performance liquid chromatography with fluorescence detection: application to red blood cells and cultured fibroblasts," Journal of Chromatography B: Biomedical Sciences and Applications, vol. 752, no. 1, pp. 123-132, 2001.

[47] R. P. Hewawasam, K. A. P. W. Jayatilaka, C. Pathirana, and L. K. B. Mudduwa, "Protective effect of Asteracantha longifolia extract in mouse liver injury by carbon tetrachloride and paracetamol," Journal of Pharmacy and Pharmacology, vol. 55, no. 10, pp. 1413-1418, 2003.

[48] M. T. Olaleye, A. C. Akinmoladun, A. A. Ogunboye, and A. A. Akindahunsi, "Antioxidant activity and hepatoprotective property of leaf extracts of Boerhaavia diffusa Linn against acetaminophen-induced liver damage in rats," Food and Chemical Toxicology, vol. 48, no. 8-9, pp. 2200-2205, 2010.

[49] T. Roušar, P. Pařík, O. Kučera, M. Bartoš, and Z. Cervinková, "Glutathione reductase is inhibited by acetaminophen-glutathione conjugate in vitro," Physiological Research, vol. 58, pp. 239246, 2009.

[50] H. Benabdeslam, H. Abidi, I. Garcia, G. Bellon, R. Gilly, and A. Revol, "Lipid peroxidation and antioxidant defenses in cystic fibrosis patients," Clinical Chemistry and Laboratory Medicine, vol. 37, no. 5, pp. 511-516, 1999.

[51] G. M. Adamson and A. W. Harman, "A role for the glutathione peroxidase/reductase enzyme system in the protection from paracetamol toxicity in isolated mouse hepatocytes," Biochemical Pharmacology, vol. 38, no. 19, pp. 3323-3330, 1989.

[52] M. Lahouel, S. Boulkour, N. Segueni, and J. P. Fillastre, "The protective effect of flavonoids against vinblastine cyclophamide and paracetamol toxicity by inhibition of lipid-peroxidation and increasing liver glutathione concentration," Pathologie Biologie, vol. 52, pp. 314-322, 2006.

[53] S. L. Arnaiz, S. Llesuy, J. C. Cutrin, and A. Boveris, "Oxidative stress by acute acetaminophen administration in mouse liver," Free Radical Biology and Medicine, vol. 19, no. 3, pp. 303-310, 1995. 
[54] M. L. Bajt, T. R. Knight, J. J. Lemasters, and H. Jaeschke, "Acetaminophen-induced oxidant stress and cell injury in cultured mouse hepatocytes: protection by $\mathrm{N}$-acetyl cycteine," Toxicological Sciences, vol. 80, no. 2, pp. 343-349, 2004.

[55] B. D. C. Pádua, J. V. Rossoni Jr., C. L. D. B. Magalhães et al., "Baccharis trimera improves the antioxidant defense system and inhibits iNOS and NADPH oxidase expression in a rat model of inflammation," Current Pharmaceutical Biotechnology, vol. 14, no. 11, pp. 975-984, 2013. 


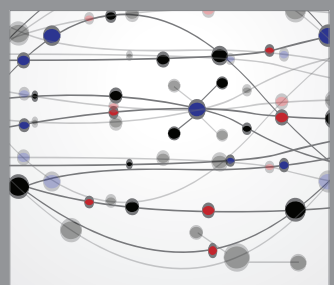

The Scientific World Journal
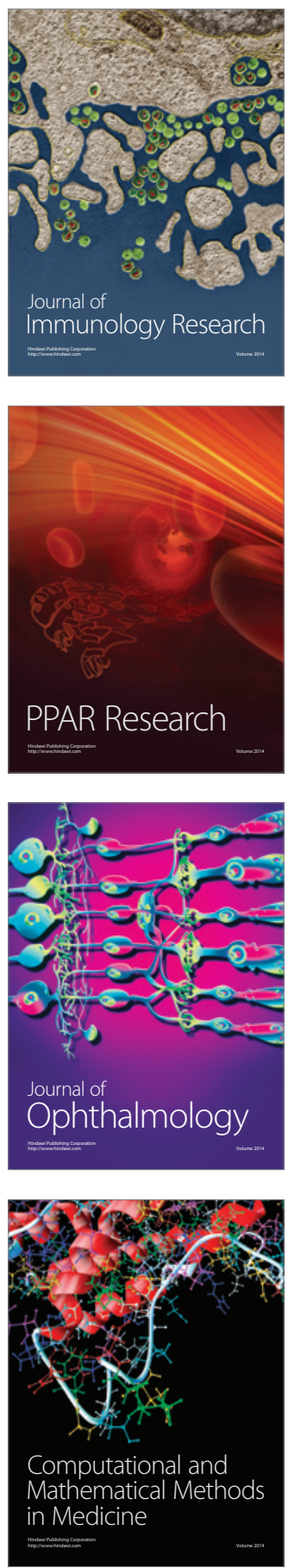

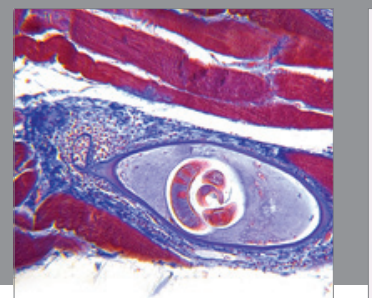

Gastroenterology

Research and Practice
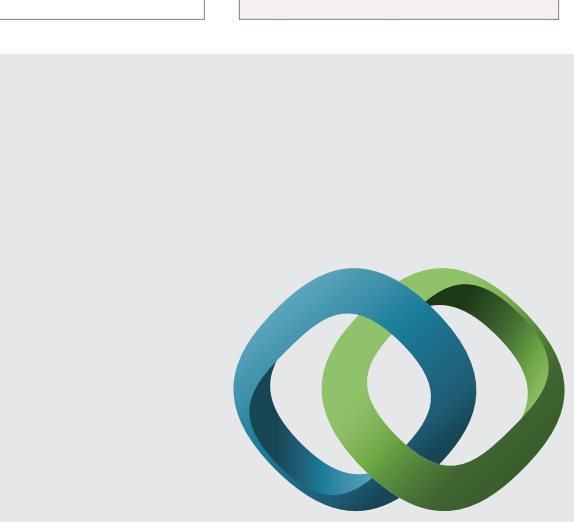

\section{Hindawi}

Submit your manuscripts at

http://www.hindawi.com
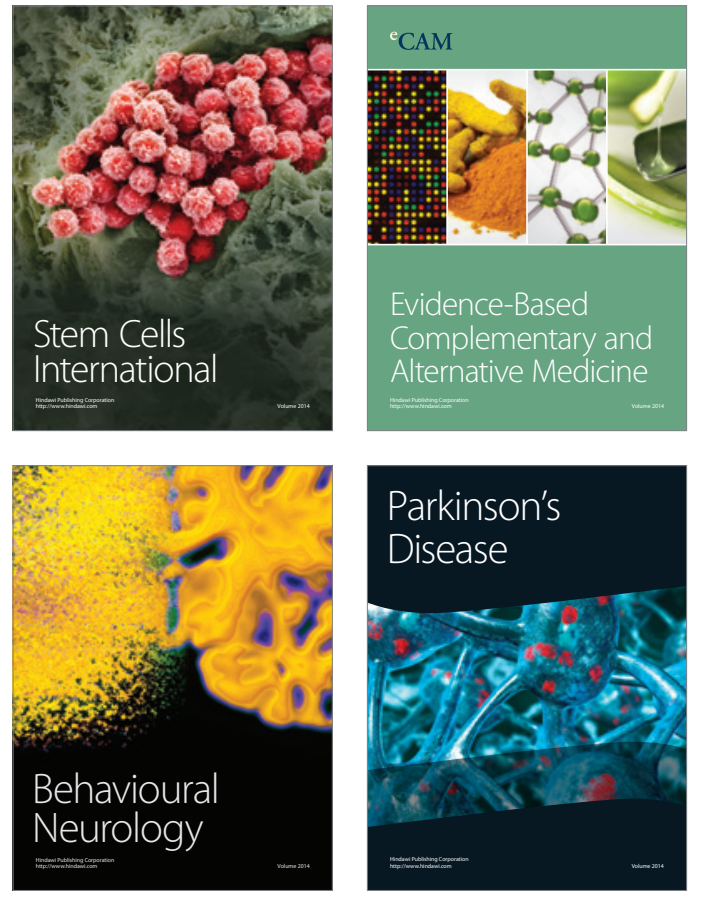
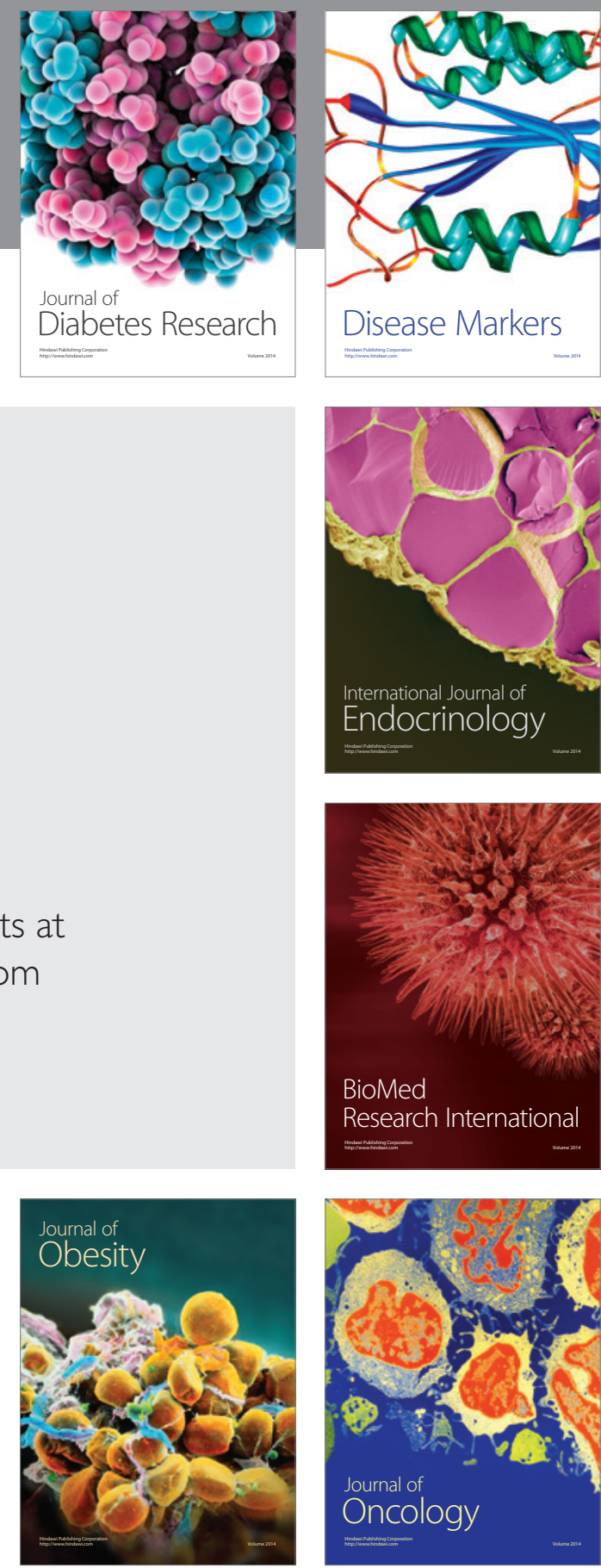

Disease Markers
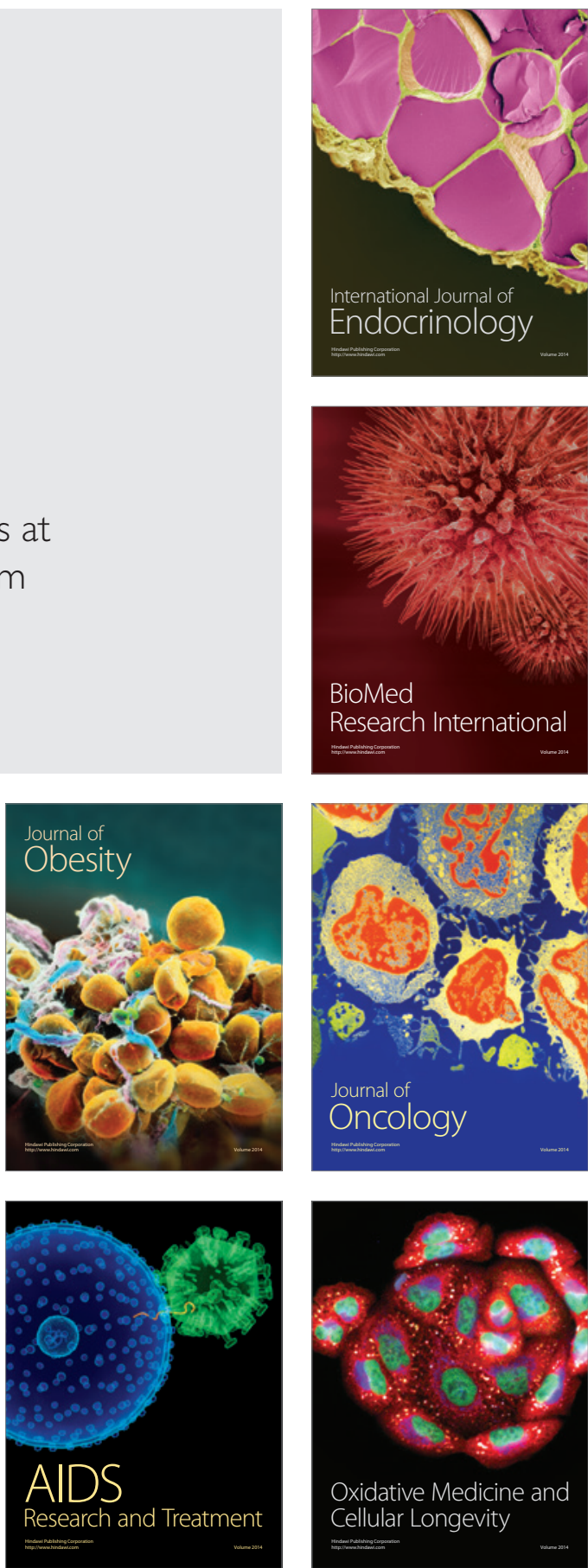